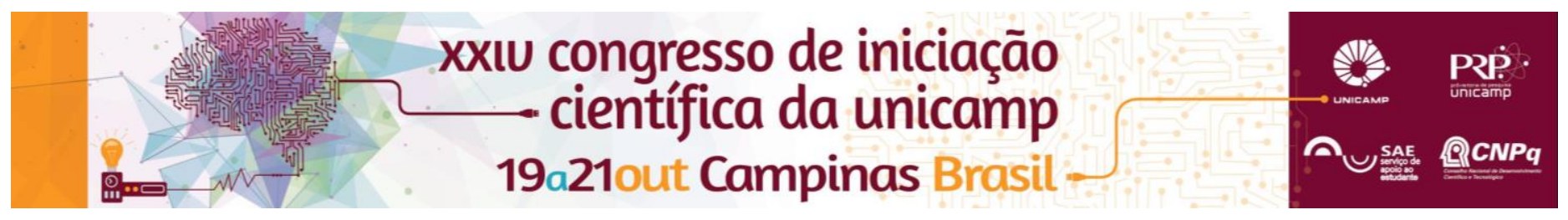

\title{
Banana drying study to construct a fruit dryer.
}

Regis R. Kato*, Gabriel G. S. Vianna, Caio F. C. Camargo, Gustavo Pereira, Rafael F. Novi.

\section{Abstract}

The aim of this study is the development of a fruit dryer designed specifically for banana producers in São Paulo State, aiming to reduce losses.

\section{Key words:}

dryed, banana, dry

\section{Introduction}

The banana is the most consumed fruit both in Brazil and in the world. The high level of losses in the banana marketing in Brazil causes only about $60 \%$ of production reaches the consumer's table.

Drying already ripe bananas to extend the shelf life is recommended to maintain its value complementing the income and avoiding disposal by the producer, overcoming the problem to get up an economically viable solution for a possible producer by using the drying process to prevent also transport damage.

\section{Results and Discussion}

It was first held two drying bananas dryer oven, in which were subjected to $60^{\circ} \mathrm{C}$ and $70^{\circ} \mathrm{C}$. Bananas were also arranged in two longitudinally drying slices of $2 \mathrm{~cm}, 5 \mathrm{~cm}$ slices and whole banana.

In a second moment was held the process in dryer columns for understanding the output for drying uniform products.

Lastly was held rotary drying columns, where the sliced bananas as described in the previous procedure, were arranged vertically following the sequence from bottom to top in one column and reversing this sequence in the other. A temperature of $65^{\circ} \mathrm{C}$ was used. The samples were identified by A1, A2, A3, B1, B2, B3 .

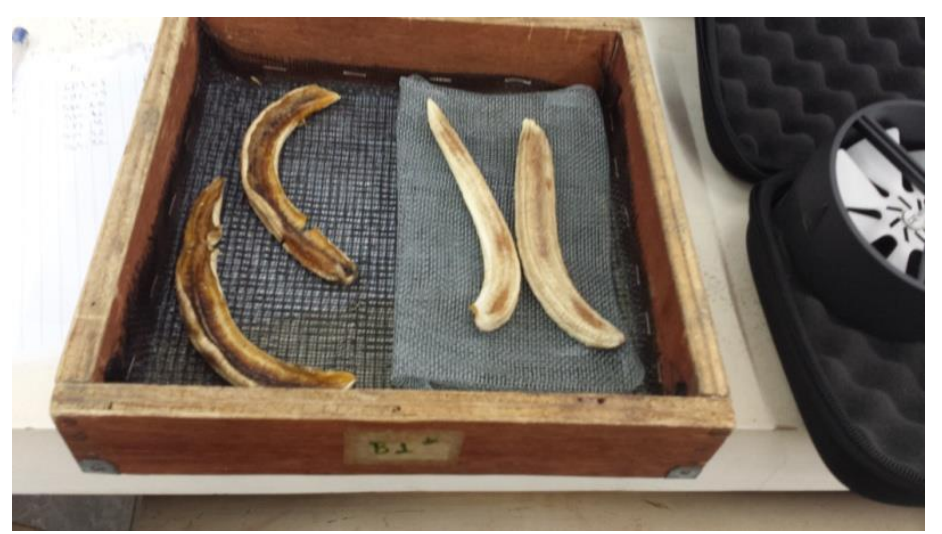

Figure 1. Bananas cut into longitudinal slices arranged in the tray of column dryer

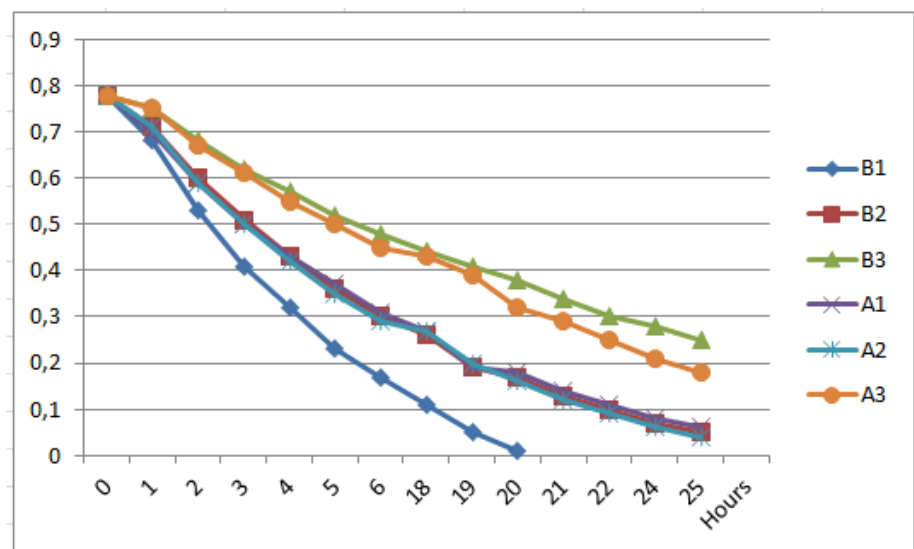

Figure 2. Moisture versus time in dryer columns

\section{Conclusions}

Analyzing the data collected, namely, initial moisture, mass average banana, drying time of each slice, temperature on each floor of the dryer, air output speed we have enough data to define what would be the drying time, depending exclusively the air outlet velocity, temperature, and were arranged as the cut banana, and those which are dried quickly sliced into $2 \mathrm{~cm}$.

The last step to conclude the research, would be the construction of a simple producer dryer and testing.

\section{Acknowledgement}

Grateful for the help from Rosa Helena Aguiar, and technicians of the Laboratory of FEAGRI, which provided care and education about the use of equipment and laboratories.

CARVALHO, F.C. Perdas na comercialização de milho no Brasil e seus impactos sócio-econômicos. In: CONGRESSO NACIONAL DE MILHO E SORGO, 19., 1992, Porto Alegre. Conferências... p. 247-258.

MASCARENHAS, G.C.C. Banana: Comercialização e mercados. Informe Agropecuário, Belo Horizonte, v. 20, n. 196, p. 97-108, jan/fev. 1999. 